\title{
Sağlık Sektöründe Bir İş Analizi Uygulaması
}

\author{
Selami ÖZCAN * \\ H. Yunus TAŞ ** \\ Yaprak BOYSAN $* * *$
}

\section{Özet}

Bir işletmede çalışan kişilerin görevlerinin tanımlanması, incelenmesi, ergonomik şartların sağlanması, fiziki imkanların iyileştirilmesine yönelik gözlem, yüzyüze görüşme ve anket yoluyla bilgilerin toplanması, toplanan bilgilerin düzenlenmesi, analiz edilerek çözümlerin üretilmesi, en uygun olan çözümün seçimi, seçilen çözümün uygulanması, uygulamanın takip edilerek kalıcı hale getirilmesi çalışmaları her zaman yapılmalıdır.

Yukarıdaki açıklamalar 1şığında yapılan bu çalışmanın amacı, iş analizin literatürde yok denecek kadar az yapıldığı sağlı sektöründe husussan performansa dayalı bir sistemin uygulandığ ve hemşirelerin yaptıkları işlerle ilgili gözlem ve görüşme yolu ile elde edilen bilgiler ışığında görev tanımların oluşturulması, görev tanımları kapsamında iş analizlerinin yapılması, iş akış diyagramlarının çizilmesi, sağ ve sol el süreç şemalarının oluşturulması, aile sağlık merkezinde 0-6 yaş grubu çocuklara, öğrencilere, yetişkinlere ve yaşlılara veya rutin bir muayeneye yönelik yapılan işlerin standart zamanlarını hesaplanması, iş akış sistemlerinin ayrıntılı bir incelemesini yapmaktır. Ayrıca yapılan inceleme ile ilgili elde edilen bilgi belge, sonuç ve önerileri yetkililere iletmektir.

Anahtar Kelimeler: İş Analizi, İş Akışı, İş Tanımları, Aile Hekimliği, Aile Sağlık Merkezi

* Doç.Dr., Yalova Üniversitesi, İİBF, İşletme Bölümü, Öğretim Üyesi / selamiozcan@hotmail. com.

** Doç .Dr., Yalova Üniversitesi, İ̈BF, Çalışma Ekonomisi Bölümü, Öğretim Üyesi / tasyunus@ hotmail.com.

*** Yalova Üniversitesi Sosyal Bilimler Enstitüsü, Yüksek Lisans Öğrencisi / yboysan.yboysan@hotmail.com. 


\title{
Application Of The Task Analysis In Health Sector
}

\begin{abstract}
Application always must be make works permanent to following via survey and face to face meeting and regulating to gathered information, generating to solutions by the way of analysis choose of the most suitable solution, applying to solution that chosen devote to developing to physical possiblies, providing to ergonomic conditions, workers' evaluating and describing in a bussiness, gathering to information.

Purpose of this work that made in the light of above statements it make that the workflow like system is to make a detailed review. in task analysis of the literature scarcely any in health sector basing on performance a system family physicians and nurses who worked family health services about their works via observation and meeting in the light of gained information consisting to tas describtion making to task analysis within tas describtion drawning to diagram of workflow building up process chart of left hand and right hand $0-6$ age group children, students and adults and olds in family health service or devote to routine inspection calculating standard time for jobs .Beside another purpose of this, suggestion, result, document, information that gained about observation to transmit to the authorities.
\end{abstract}

Key Words: Task Analysis, Workflow, Work Statements, Family Physician, Family Health Service

\section{Giriş}

Üretim faktörlerinden mümkün olan maksimum faydayı elde etmek için faktörler arasındaki ilişkilerin bilinmesi, düzenlenmesi ve ölçülmesine yönelik sistematik araştırmaların tümüne iş analizleri denir (Kobu, 1999:329). Diğer bir iş analizi tanımı ise, üretim veya hizmet sisteminin verimliliğini arttırmak, sistemde kullanılan girdilerden (malzeme, makine ve işgücünden) en iyi çıktının elde edilmesine yönelik yapılan bir çalışmalara denir (Tekin, 1996:153). İş analizi, bir işin maliyetini azaltmak, yapılış süresini kısaltmak ve yapılış tarzını kolaylaştırmak amacıyla işle ilgili

YIL: 5 SAYI: 10 
tüm faaliyetlerin planlı bir şekilde ele alınması ve geliştirilmesi sürecidir. İş analizi bilinenin aksine sanayi sektöründen daha çok hizmet sektörüne yönelik yapılması durumunda daha başarılı olur. Çünkü hizmet sektörü emek yoğun bir sektördür.

Türkiye Cumhuriyeti Sağlık Bakanlığı, sağlık sektöründeki uygulamaları 15 Eylül 2004 tarihi itibariyle değiştirmiştir. Bu değişiklikle "Sağlık Ocakları" yerine “Aile Sağlık Merkezleri” (ASM) sistemi kurulmuş ve ASM'de çalışan sağlık çalışanlarının görevleri de yeniden tanımlanmıştır. İlk olarak ASM'de asgari fiziki şartlar ve kriterleri hakkında bilgi verilecektir.

Aile Sağlık Merkezi kriterleri, Bakanlıkça öngörülen nüfus kriterlerini esas alınmak suretiyle, sözleşme yapmış bir ya da birden fazla aile hekimi tarafından açılabilir ve aynı aile sağlığı merkezinde görev yapan her bir aile hekimi ayrı ayrı sözleşme yapmak zorundadır. Aile Sağlığı merkezleri aşağıdaki asgari fiziki şartları sağlamalıdır: (Bursa Sağlık Müdürlüğü Aile Hekimliği Uygulama Rehberi, 2009)

\section{$\underline{\text { Aile Sağlığı Merkezlerinde Bulunması Gereken Özellikler }}$}

- Bina, kolay ulaşılabilir, güvenli, uygun havalandırma ve aydınlatma imkanlarına sahip olmalıdır. Toplam alanı bir aile hekimi için 60 metrekaredir. Birden fazla hekimin çalışması durumunda ise, her aile hekimi için 20 metrekare eklenir.

- Bekleme ve Sekreter kayıt odası bulunmalıdır.

- Muayene odası her aile hekimi için en az 8 metrekare olmalıdır.

- Tıbbi müdahale odası, hastaya tıbbi girișimlerin yapılabileceği ve sterilizasyon cihazlarını alabilecek büyüklükte olmalıdır. Bu odada aşı, enjeksiyon, küçük cerrahi müdahalelerin yapılmasına uygun muayene ve müdahale masası, jinekolojik muayene masası ve bu muayeneler için acil müdahale malzemeleri, dezenfeksiyon ve sterilizasyon cihazlarının bulunması gereklidir. 
$34 \cdot$ YALOVA SOSYAL BILIMLER DERGISI

- Çalıştırılması planlanıyorsa, laboratuvar cihazlarının bulundurulacağı ve çalıştırılacağı uygun bir oda bulunmalıdır.

- Sağlık kayıtlarının tutulacağı, dosyalama, istatistik tutma, resmi kurum ve sigorta kurumlarına yapilacak bildirimlerin hazırlanması gibi çalışmaların yapılacağı arka büro veya bir bölme bulunmalidir.

- Hastaların kullanabileceği ayrı bir lavabo ve tuvalet olmalıdır.

Yukarıda belirtilen tüm fiziki koşullar, Mudanya Aile sağlığı merkezilerinin tamamında gözlemlendiği gibi, araştırma alanı olan Mudanya 2.No'lu ASM'de yönetmelikte belirtilen tüm fiziki şartlar mevcuttur. Araştırma kapsamında yer alan 2.no'lu ASM ile ilgili genel bilgiler vermek gerekirse şunlardır:

- Mudanya 2.no'lu Aile Sağlı̆̆ı Merkezi'nde 5 adet Aile Hekimi bulunmaktadır. Hepsi Pratisyen hekim olup, 5 aile hekiminin de birer adet hemşiresi bulunmaktadır.(Hemşireler sekreterlik işlemlerini de yerine getirmektedir).

- Her bir doktorun ortalama 4000-4500 hastasi bulunmaktadır.

- Bir adet Hizmetli sıfatında çalışan personel bulunmaktadır.

- 1 Kişi de laboratuvar da çalışmak sureti ile hemşire olarak çalışmaktadır.

- Tüm hemşireler, hemşirelik görevlerinin yanı sıra, "ebe"lik görevleri ve ünvanları da bulunmaktadır.

\section{Mudanya 2.No'lu Aile Sağlığı Merkezinde İş Analizi Çalışması}

\section{Aile Hekimi}

\subsection{Görev Tanımları}

Aile hekimliğini, tüm yaş, cins, organ ve hastalığ 1 kapsayan bir uygulama alanında, fiziksel, ruhsal ve sosyal yapısı ile bir bütün olarak değerlendirilen uzmanlık alanı olarak betimlemek mümkündür (Tekin, vd., 2010:13). Birinci basamak sağlık hizmeti vermektedirler ve gerektiği 
durumlarda ikinci ya da üçüncü basamakta görev yapan daha teşkilatlı hastanelere yönlendirme yapmaktadırlar (Şahin,2013). Bireylerin ve aile fertlerinin ikametlerinin yakınlarında ya da kolaylıkla ulaşabilecekleri bir yerde bulunan, ilk başvuracakları ve sağlık hizmetini alacakları hekimlik uygulaması, aile hekimlerinin iş tanımına girmektedir. Bu hekimler, koruyucu hekimlik uygulamaları ile birlikte, ayakta tanı ve tedavi işlemlerinin büyük çoğunluğunu üstlenmektedirler (Korukluoğlu, vd., 2004: 15).

Mudanya 2 No'lu Aile Sağlığı Merkezi'nde (ASM) de aynı görevler icra edilmektedir. Tablo:1'de hekimlerden ayrıntılı olarak alınan bilgiler doğrultusunda hazırlanan Aile hekimine ait görev tanımı verilmiştir. Genel olarak görev tanımları, iş analizi çalışmasının bir uzantısıdır ve iş analizi çalışmasından sonra ikinci aşama olarak mutlka görev tanımlarından söz edilmektedir. Görev tanımı formlarında, işin özellikleri, gerekleri, sorumluluklar ve işin içeriğinin yer aldığı bilgiler düzenli bir şekilde işlenmektedir (Sabuncuoğlu, 2011).

Tablo 1: Aile Hekimi Görev Tanımı

\begin{tabular}{|c|c|}
\hline & AİLE HEKİMİ \\
\hline$\dot{I}_{S} \sin \operatorname{Kodu}$ & $00001 \quad$ Aile Hekimi \\
\hline Bölümü & Mudanya 2 No'lu Aile Sağlığı Merkezi \\
\hline $\begin{array}{l}\text { Bağll Olduğu Üst } \\
\text { Görev }\end{array}$ & Bursa İl Sağllk Müdürlüğü \\
\hline $\begin{array}{l}\text { Kendisine Băgll } \\
\text { Görevler/Ünvanlar }\end{array}$ & Hemşire/ebe hemşire, Laboratuvar Hemşiresi, Hizmetli \\
\hline İşin Amacl & \multirow{2}{*}{$\begin{array}{l}\text { Doktorun ikamet ettiği bölge de olan ya da olmayan (misafi } \\
\text { hasta) tüm hastalara birinci basamak sağlı hizmeti vermek } \\
\text { suretiyle, hastaların tüm ihtiyacını karşılamak, yönlendirmek } \\
\text { tüm toplumun sağlığını düşünerek etik kurallar çerçevesinde } \\
\text { hekimliğini sürdürmektir. }\end{array}$} \\
\hline & \\
\hline
\end{tabular}




\begin{tabular}{|c|c|}
\hline \multirow{12}{*}{$\begin{array}{l}\text { Yapılması Gereken } \\
\text { İsler }\end{array}$} & $\begin{array}{l}\text { Birinci basamak sağlı hizmeti verilmek suretiyle hasta } \\
\text { muayene etmek, }\end{array}$ \\
\hline & $\begin{array}{l}\text { Hastaları, önemli ya da hayati önem taşıyan hastalıklarda } \\
\text { ikinci ya da üçüncü basamak sağlık hizmeti veren kuruluşlara } \\
\text { yönlendirmek, }\end{array}$ \\
\hline & $\begin{array}{l}\text { Rutin hasta bakımları için ( çocuk aşıları, gebe takipleri vb.) } \\
\text { hemşire ile koordineli çalıșma yürütmek, }\end{array}$ \\
\hline & $\begin{array}{l}\text { Sigarayı bıraktırma, zararlı maddeleri halktan uzaklaştırma } \\
\text { gibi faaliyetleri kapsayan bir eğitim planı ile hastaları, halkı } \\
\text { ve tiryakileri bilinçlendirmek, }\end{array}$ \\
\hline & $\begin{array}{l}\text { Tedavi edilen hastaların kayıtlarını veri tabanına işleyip, } \\
\text { sağlık müdürlüğüne ve bakanlığına göndermek, }\end{array}$ \\
\hline & $\begin{array}{l}\text { Ehliyet yeterliliği, Adli melekeler, sporcu raporları ve sağlık } \\
\text { durumlarının son raporları, avcıların yivsiz silah }\end{array}$ \\
\hline & $\begin{array}{l}\text { bulundurma raporları gibi bazı yetkili mercilerden istenen } \\
\text { hususi raporların tedavi sonucuna göre verilmesi, }\end{array}$ \\
\hline & $\begin{array}{l}\text { Ölüm halinde hazırlanan defin raporlarının düzenlenip } \\
\text { hazırlanması. (mesai saatleri içerisinde her hekim kendi } \\
\text { hastasının defin raporunu düzenlemekte yükümlüdür. }\end{array}$ \\
\hline & $\begin{array}{l}\text { Öğrencilerin, gerekli durumlar da periyodik olan aşılarının } \\
\text { yapılması ve hemşirelerle birlikte koordineli olarak çalışarak, } \\
\text { aşılama için okula gidilmesi ya da Aile Sağlık Merkezine } \\
\text { çăgırılması,. }\end{array}$ \\
\hline & $\begin{array}{l}\text { Tüberküloz, kanser gibi toplumsal hastalıklar için izlem } \\
\text { yapılması, }\end{array}$ \\
\hline & $\begin{array}{l}\text { Evde bakılan yatalak hastalara durum analizi yapılıp, } \\
\text { bakımının evde mi yoksa hastanede mi devam edeceğinin } \\
\text { karar verilmesi. }\end{array}$ \\
\hline & $\begin{array}{l}\text { Tetkik hizmetleri verilmesini sağlamak ya da buz hizmetleri } \\
\text { bizzat vermektir. }\end{array}$ \\
\hline
\end{tabular}

YIL: 5 SAYI: 10 


\begin{tabular}{|c|c|c|c|c|}
\hline \multicolumn{5}{|l|}{ SORUMLULUK } \\
\hline Genel Sorumluluk & Düşük & Yüksek & Yok & Orta \\
\hline Kendi İşinden & & $\mathrm{X}$ & & \\
\hline Çalışanların İşinden & & $\mathrm{X}$ & & \\
\hline Bilgi Paylaşma & & $\mathrm{X}$ & & \\
\hline Araç-Gereç-Malzeme & & $\mathrm{X}$ & & \\
\hline Koordinasyon & & $\mathrm{X}$ & & \\
\hline Iş̧S Sürekliliği & & $\mathrm{X}$ & & \\
\hline $\begin{array}{l}\text { Süreçlerin denetim ve } \\
\text { Gözetimi }\end{array}$ & & $\mathrm{X}$ & & \\
\hline Raporlama & & $\mathrm{X}$ & & \\
\hline $\begin{array}{l}\text { Sürekli eğitim ve } \\
\text { Gelişstirme }\end{array}$ & & $\mathrm{X}$ & & \\
\hline Hasta Sorumluluğu & Düşük & Yüksek & Yok & Orta \\
\hline Kurum İçi & & $\mathrm{X}$ & & \\
\hline Kurum Dışı & & $X$ & & \\
\hline
\end{tabular}




\begin{tabular}{|c|c|}
\hline \multicolumn{2}{|l|}{ YETKILLERI } \\
\hline \multirow{9}{*}{ Genel } & $\begin{array}{l}\text { Sorumluluğu altında çalışanları (hemşire, laboratuvar } \\
\text { sorumlusu vb) yönetmek, koordinasyonunu sağlamak ve } \\
\text { yönlendirmek. }\end{array}$ \\
\hline & $\begin{array}{l}\text { Bebek, çocuk, yaşlı ve gebelerin sağlık durumları hakkında } \\
\text { hemşirelerden bilgi alıp çeşitli kararlar vermek, }\end{array}$ \\
\hline & $\begin{array}{l}\text { Yasal düzenlemeler çerçevesinde sağlık merkezinin yeniden } \\
\text { yapılanmasını ya da düzenlemelerin oluşturulmasını } \\
\text { sağlamak, }\end{array}$ \\
\hline & $\begin{array}{l}\text { Muayene gereçleri, laboratuvar malzemeleri gibi ihtiyaç } \\
\text { ürünlerinin giderilmesini talep etmek, }\end{array}$ \\
\hline & $\begin{array}{l}\text { Kişilerin çeşitli raporlarını tastik etmek (sporcu, avcı, ehliyet } \\
\text { yeterlilik ya da öğrenci hastalık onay raporları) }\end{array}$ \\
\hline & $\begin{array}{l}\text { İl sağlık müdürlüğünde belirtilen kriterleri oluşturmak ve } \\
\text { tamamlamak }\end{array}$ \\
\hline & $\begin{array}{l}\text { Reçete yazma ve onay, hastalık onay ve hangi ilaçların } \\
\text { verileceği konusunda karar vermek }\end{array}$ \\
\hline & $\begin{array}{l}\text { Hastalık teşhisi ve gerektiğinde ikinci ya da üçüncü basamak } \\
\text { sağlık hizmetlerine yönlendirmek }\end{array}$ \\
\hline & $\begin{array}{l}\text { Toplumsal hastalıklar konusunda kurum içi sağlık çalışanlarını } \\
\text { halka bilinçlendirme yapması konusunda talimat vermektir. }\end{array}$ \\
\hline \multicolumn{2}{|l|}{ IŞ GEREKLERI } \\
\hline Çalışan Profili & Aile Hekimi \\
\hline Ĕgitim & $\begin{array}{l}\text { En az } 6 \text { yıllık tıp fakültesi mezunu (mezuniyet sonrası } 4 \text { yıllık } \\
\text { "Aile Hekimliği Uzmanlığı Diploması") }\end{array}$ \\
\hline Deneyim & Kıdem esastır.( En az 8-10 yıl aras1 ) \\
\hline $\begin{array}{l}\text { Bilgisayar } \\
\text { Programlarl }\end{array}$ & $\begin{array}{l}\text { İleri düzey ( Sağlık Bakanlı̆̆g’'nın düzenlediği Aile Hekimliğ } \\
\text { Hasta Giriş-Kontrol-Reçete Programları) }\end{array}$ \\
\hline Muayene Gereçleri & İleri Düzey \\
\hline Cinsiyet & Erkek / Bayan \\
\hline
\end{tabular}




\begin{tabular}{|c|c|}
\hline \multirow{13}{*}{$\begin{array}{l}\text { Alması Gereken Ek } \\
\text { Ĕgitimler }\end{array}$} & Aile Hekimliği sertifikası (Aile Hekimliğinin ön şartı) \\
\hline & Sağlık mevzuatıyla ilgili mevcut ve yenilenen tüm eğitimler \\
\hline & Hasta ve hekim hakları eğitimleri ve malpraktis \\
\hline & $\begin{array}{l}\text { İl Sağlık Müdürlüğü’nün periyodik olarak hazırladığı tüm } \\
\text { eğitim programları ve web üzerinden istenilen zamanda tüm } \\
\text { eğitim programlarını tamamlamak }\end{array}$ \\
\hline & Cinsel hastalıklardan korunma tedavi tanı yöntemleri \\
\hline & Aşılama programları \\
\hline & Rahim içi araç takma (Ria) \\
\hline & Aile içi şiddet eğitimi \\
\hline & EKG eğitimi \\
\hline & Hayvan 1sırıkları tedavi ve acil müdahale yöntemleri \\
\hline & $\begin{array}{l}\text { İshal, zehirli ishal gibi son yıllarda yoğunlaşan hastalıklarla } \\
\text { güncel tedavi yöntemleri }\end{array}$ \\
\hline & Çocuk hastalıkları birinci adım tanı yöntemleri \\
\hline & Tüm hastalıklarla ilgili olan tedavi ve tanı yöntemleri eğitimi \\
\hline
\end{tabular}

Mudanya 2 No'lu Aile Sağlığı Merkezi'nde bir Aile Hekiminin görev tanımı, sorumlulukları ve yapmakla sorumlu olduğu işler yukarıda belirtildiği gibidir. Üç haftalık Aile Sağlık Merkezi'nde yapılan araştırma doğrultusunda, ilk olarak yapılan işlerden bir örnek olarak akış diyagramı şekil 1 'de gösterilmiştir.

İş akış diyagramları (şeması) genellikle, yapılan iş ile ilgili bilgileri düzenli ve açık-seçik göz önüne sermek amacına hizmet etmektedir. Metot etüdü kapsamına girmekle beraber, ilgili bilgilerin kayıt edilmesi için geliştirilmiş diyagramlardır ( Özcan, vd., 2011).

\subsection{Aile Hekimi Muayene Akış Diyagramları ve İşlem Analizleri}

Gün içerisinde Aile Sağlık Merkezi’nde görevli olan tüm sağlık çalışanları belirli bir sürede ve belirli bir sistem çerçevesi içerisinde işlerini yapmaktadırlar. Hekim ve hemşirelerin işleri genellikle tekdüze olmayıp, hastasına, rahatsızlığına göre tamamen değişmektedir. Sabit bir görev akış1 olmamakta birlikte genellikle; Hastaların doktor muayene sırası için 
fiş almasıyla başlayıp, muayene edilmesi ve e-reçeteyle tamamlanan ya da ikinci/üçüncü basamak sağlık merkezlerine gönderilmek suretiyle son bulmaktadır. Hemşirelerin görev süreçleri ise daha karmaşık ve çok daha farklı alanlara ayrılmaktadır. Bu daha sonraki hemşireler için ayrıca analiz yapılan kısımda belirtilecektir.

Aşağıdaki akış diyagramı; kontrol amaçlı hafif ateş ve öksürük şikayetiyle aile hekimine çocuğunu getiren bir bayanın hekimin odasına girişinden çıkışına kadar işleyen süreçte, doktorun muayene aşamasını göstermektedir. İnceleme, Sabah 08.00 da başlamış ve 16.30 da sona eren sıradan bir işgünü içerisinde gerçekleşmiştir. Genel bir iş sürecinden ziyade, daha spesifik bir örnek ile hastalık teşhis sürecini izlem altına alınmıştır.

\section{Şekil. 1. Hasta Muayene İş Akış Diyagramı}

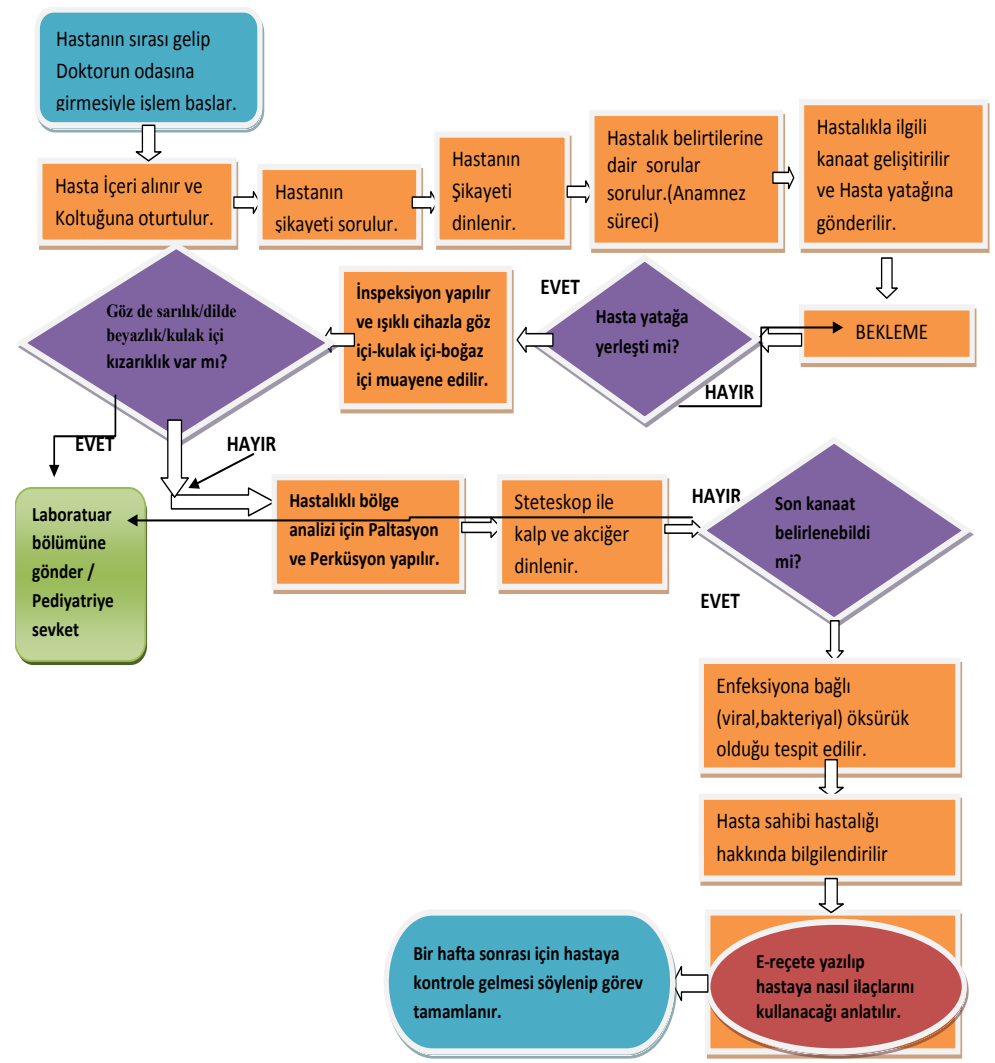

YIL: 5 SAYI: 10 
Şekil:1' de, rutin hasta şikâyetinden bir süreci, akış diyagramı olarak aktarılmıştır. Ancak, genellikle sabit bir süreç işlememekte ve her hasta ya da tanı için farklı süreçler işleyebilmekte ve zaman harcanabilmektedir. Şekil 1'de ki akış diyagramının uygulamada ki süresi 10 dakikada gerçekleşmiştir.

Bazı hastalar için 2-5 dakikalık zaman yeterli oluyor iken, bazı hastaların bakımı 10 dakikaya kadar çıkabilmektedir.

\section{Şekil 2. Reçete Yazma İş akış Diyagramı}

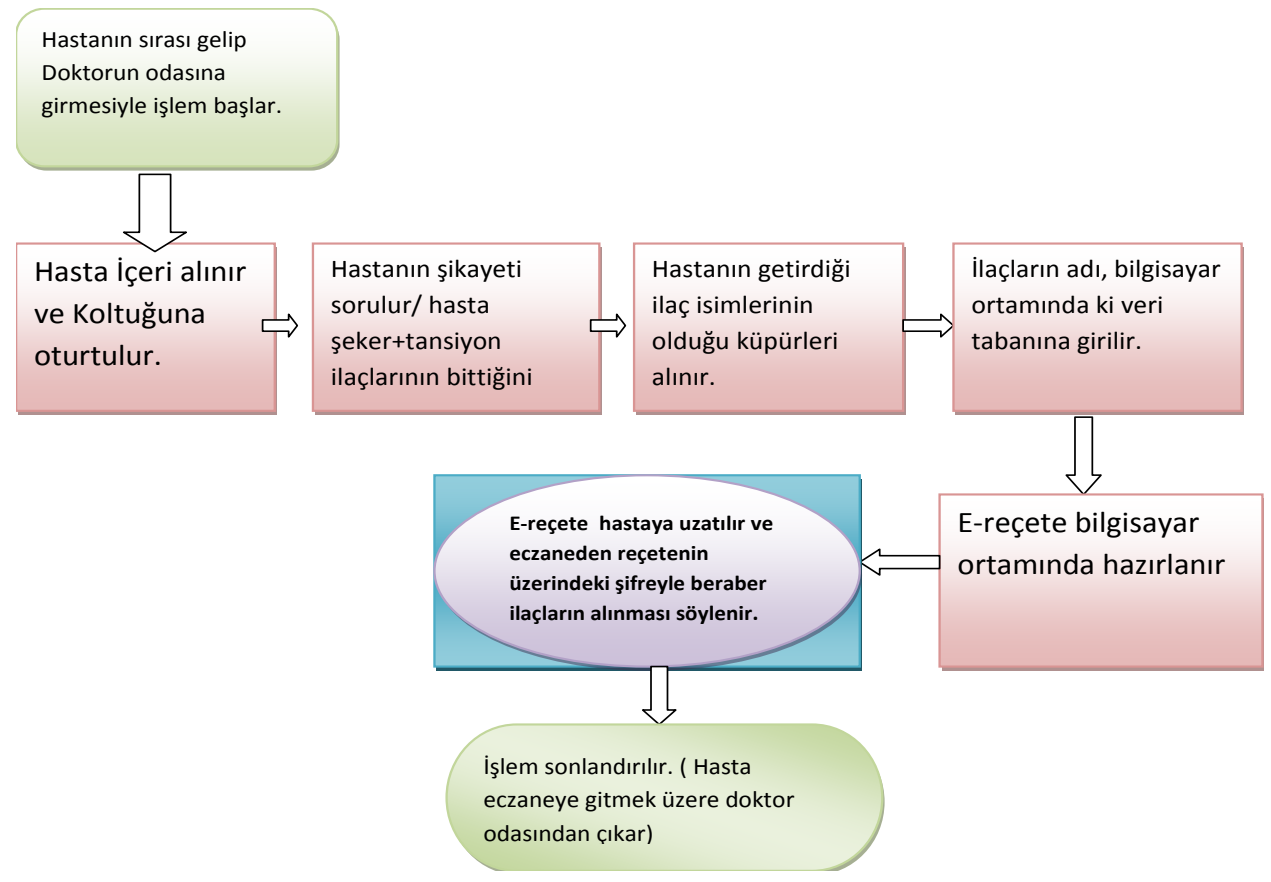

Şekil: 2'de görüldüğü üzere, bir hekimin hastasının isteği üzerine ilaç yazdırma (Reçete) işlemi gerçekleştirilmiştir. Hastanın hekimin odasına girip, işlemini gerçekleştirip odadan çıkması 2 dakikadır. Hekimin veri tabanına bakıldığında bu süreç, 10.51 - 10.53 arası gerçekleşmiştir

İzlenilen tüm muayene, reçete yazma, vb. süreçleri tüm doktorlarda hemen hemen aynı olduğu gözlemlenmiştir. ASM'de toplam 5 hekim 
bulunduğunu en başta belirtilmiştir. Ancak burada, 2 hekimden edinilen gözlem ve analizler karşılaştırıldığında çıkan standart süreler aşağıdaki tablo 2.'de gösterilmiştir.

Tablo.2: Standart İşlem Süreleri

\begin{tabular}{|l|l|l|l|l|}
\hline \multirow{2}{*}{} & \multicolumn{2}{|l|}{ A Hekimi } & \multicolumn{2}{l|}{ B Hekimi } \\
\cline { 2 - 5 } & $\begin{array}{l}\text { İşlem } \\
\text { Yapılan Kişi } \\
\text { Sayıs1 }\end{array}$ & $\begin{array}{l}\text { Ortalama } \\
\text { İşlem Süresi }\end{array}$ & $\begin{array}{l}\text { İşlem } \\
\text { Yapılan Kişi } \\
\text { Sayıs1 }\end{array}$ & $\begin{array}{l}\text { Ortalama } \\
\text { İşlem Süresi }\end{array}$ \\
\hline Gebe izlem & 2 & $4 \mathrm{dk}$. & 1 & $2 \mathrm{dk}$. \\
\hline $\begin{array}{l}\text { Bebek } \\
\text { izlem }\end{array}$ & 1 & $5 \mathrm{dk}$. & 2 & $3.8 \mathrm{dk}$. \\
\hline Muayene & 65 & $4.9 \mathrm{dk}$. & 93 & $3.9 \mathrm{dk}$. \\
\hline Aş1lama & 2 & $9.5 \mathrm{dk}$. & 4 & $1.8 \mathrm{dk}$. \\
\hline $\begin{array}{l}\text { 15-49 Yaş } \\
\text { kadın }\end{array}$ & 13 & $3.8 \mathrm{dk}$. & 3 & $2.3 \mathrm{dk}$. \\
\hline $\begin{array}{l}\text { Loğusa } \\
\text { İzlem }\end{array}$ & 1 & $6 \mathrm{dk}$. & 1 & $8 \mathrm{dk}$. \\
\hline $\begin{array}{l}\text { Obezite } \\
\text { İzlem }\end{array}$ & 3 & $7.4 \mathrm{dk}$. & & \\
\hline Toplam & 87 & $4.9 \mathrm{dk}$ & 104 & $3.7 \mathrm{dk}$ \\
\hline
\end{tabular}

Tablo.2 'de görüldüğü gibi, haftanın bir günü, bir hekim toplam 87 hastaya; kişi başına ortalama 4.9 dakika ayırıyorken; diğer hekim 104 hastaya 3.7 dakika ayırmaktadır. Bu istatistiklerin, bir günü baz alınarak yapıldığını varsayıldığında ve her gün hasta profilinin değiştiğini düşünüldüğünde rakamlar arasında çok uçurum olmadığı sonucu çıkarılmaktadır. Ancak belirtmek gerekir ki; hekim ile hemşirelerin veri tabanları ortak olduğundan ve bazı durumlarda hekimler hastalarını hemşirelerine yönlendirdiği için süreler arasında açılma olabilmektedir. Örneğin; A Hekiminin yaptığı aşı işlemi süresi 9.5 dakikada 2 kişi iken; B Hekimi, ortalama 1.8 
dakikada 4 kişi gözükmektedir. Bunlar kişi başına düşen sürelerdir. $\mathrm{Bu}$ açıdan bir aşılama işlemi hemşireye yönlendirilip başka tetkiklerde aradan çıkarılıyorken; diğer hekim aşıyı tamamlayıp işlemi bitirmiş olabilmektedir.

Yukarıda belirtilen sonuçların yanında, bir hekimin 'iki el proses (akış) şeması" incelendiğinde, işin daha da detayına inmiş olunacaktır. İki el proses şemaları, çalışanın elleriyle yaptığı ve birbiriyle ilişkili olan faaliyetlerin kaydedilmesinde kullanılan şemalardır. İş akış şemalarının özel bir türüdür ve genellikle tekrarlanan faaliyetlerin çok olduğu işler için yararlı bir kayıt tekniğidir (Kurt ve Dağdeviren, 2003). İki el sağ ve sol el şemalarında süre ifade edilmez (Doğruer, 2008: 83). Buna göre, hekimin yaptığı muayene işlemi, iki el proses şemasında detaylı bir şekilde ve belirli semboller ile aktarılacaktır.

Kullanılan sembollerin manası şu şekildedir: (Özcan vd., 2011: 38)

İşlem, araç, malzeme ve parçaları kavrama yakalama, koyma, yerleştirme, çıkarma, kullanma ve bırakma vb. işlemler için kullanılır.

Taşıma, el, kol ve ayakların bir noktadan işe ve işten, araca ve araçtan, malzemeye takip ettiği hareketleri göstermek için kullanılır.

Bekleme, gecikme, boş kalma; elin ve kolun boş anlarını veya malzemeden ayrı kalma durumunu gösterir.

Tutma, iki el proses şemasında depolama terimi yerine tutma terimi kullanılır. Eldeki işin araç ve malzemenin tutulma durumudur.

Kontrol, muayene, denetim ve kontrol işlemlerini ifade eder.

Çocuk muayene işlem sıralaması aşağıdaki gibidir.

1. Hasta içeriye girer

2. Hasta koltuğa oturtulur

3. Hastaya şikayeti sorulur

4. Gerekli muayene yapılır

5. Hasta hakkında kanaat geliştirilir 
$44 \cdot$ YALOVA SOSYAL BILIMLER DERGISI

6. Hastaya rahatsızlığ ve nedeni belirtilir

7. Gereken ilaçlar yazılır

8. İlaçların nasıl kullanılacağı açıklanır

9. E-Reçete yazılır

10. Hastaya ilaçlarının nasıl kullanılacağı açıklanır

11. Hastanın 1 hafta sonra kontrole gelmesi söylenir

12. Süreç tamamlanır.

$\mathrm{Bu}$ sürece istinaden, bir hekimin yukarıdaki sürece bağlı olarak uyguladığ1 el hareketlerinin gösterildiği sağ ve sol el proses şeması örneğinin adımları aşağıda belirtilmiştir.

Şekil 3: Ç̧ocuk Muayene İşleminde Sağ ve Sol El Proses Şeması Örneği

\begin{tabular}{|l|l|l|l|l|l|}
\cline { 2 - 6 } \multicolumn{1}{c|}{} & \multicolumn{3}{c|}{ SAGEL } & \multicolumn{2}{c|}{ SOL EL } \\
\cline { 2 - 6 } \multicolumn{1}{c|}{} & ADET & ZAMAN & ADET & ZAMAN \\
\hline & IŞLM & 6 & 230 & 3 & 70 \\
\hline & TAŞIMA & 2 & 10 & & \\
\hline & TUTMA & 1 & 10 & 1 & 10 \\
\hline & BEKLEME & 4 & 248 & 7 & 376 \\
\hline & KONTROL & 1 & 2 & 3 & 52 \\
\hline
\end{tabular}


Şekil 4: Hasta Muayene

\begin{tabular}{|c|c|c|c|c|c|c|c|c|c|c|c|c|c|c|}
\hline $\begin{array}{l}N \\
0\end{array}$ & Iș & :ี & 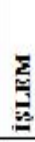 & $\underset{5}{5}$ & $\frac{5}{2}$ & 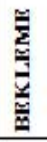 & $\begin{array}{l}\bar{b} \\
\bar{z} \\
\mathscr{z}\end{array}$ & 尝 & $\begin{array}{l}\vec{j} \\
\stackrel{y}{z} \\
z \\
\underline{z}\end{array}$ & 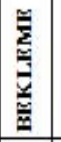 & $\stackrel{5}{5}$ & $\underset{5}{5}$ & $\underset{z}{E}$ & İș \\
\hline 1 & $\begin{array}{l}\text { Hasta ismine ekrandan } \\
\text { bak }\end{array}$ & 2 & & & & & $\square$ & 2 & & & & & & Hastayniçeri çağr \\
\hline 2 & $\begin{array}{l}\text { Hastanın içeri } \\
\text { girmesini bekle }\end{array}$ & 12 & & & & & & 12 & $\square$ & & & E & & $\begin{array}{l}\text { sistemden kișiyi } \\
\text { tamı }\end{array}$ \\
\hline 3 & $\begin{array}{l}\text { Oturmasımı } \\
\text { soỵle șikayetimi sor }\end{array}$ & 186 & & & & & $\square$ & 186 & & & & & & Ekrana bak \\
\hline 4 & $\begin{array}{l}\text { Yatağa uzanmasımı } \\
\text { söyle }\end{array}$ & 50 & & & & & ㅁ & 50 & D & & & 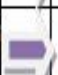 & & $\begin{array}{l}\text { Hasta yatağnnn } \\
\text { yanma git }\end{array}$ \\
\hline 5 & Karnına bastır-çek & 20 & & & & & & 20 & & & & & & kontrol et \\
\hline 6 & $\begin{array}{l}\text { Karnina } \\
\text { vur(perküsyon) }\end{array}$ & 25 & & & & & 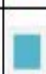 & 25 & & & & & & dokun \\
\hline 4 & Steteskopu masadan al & 8 & & & & & 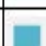 & 8 & $\bar{T}$ & & & & & Masaya git \\
\hline 5 & Surtı dinle/öksürt & 35 & & & & & D & 35 & $\square$ & & & & & $\begin{array}{l}\text { Steteskop baș̣nı } \\
\text { surta koy }\end{array}$ \\
\hline 6 & Kalbi dinle & 20 & & & & & & 20 & 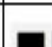 & & 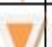 & & & Steteskopu sabitle \\
\hline 7 & Masaya git & 8 & & & & & 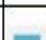 & 8 & - & & 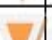 & & & \begin{tabular}{|l} 
Masaya git \\
\end{tabular} \\
\hline 8 & $\begin{array}{l}\text { Bilgisayarda mauseye } \\
\text { dokun/sistemi aç }\end{array}$ & 10 & & & & & 口 & 10 & $\square$ & & & E & & $\begin{array}{l}\text { Bilgisayarda } \\
\text { mauseye } \\
\text { dokun sistemi ac }\end{array}$ \\
\hline 9 & $\begin{array}{l}\text { Verilecek ilaç isimlerimi } \\
\text { sisteme gir }\end{array}$ & 120 & & & & & $\square$ & 120 & 들 & & & E & & Sisteme bak \\
\hline 10 & Yazıcidan e-reçeteyi al & 10 & & & & & $\square$ & 10 & T & & & & & $\begin{array}{l}\text { Yazccidane- } \\
\text { reçeteyi al }\end{array}$ \\
\hline 11 & E-reçeteyi hastaya a ver & 2 & & & & & & 2 & & & & & & $\begin{array}{l}1 \text { hafta sonrass için } \\
\text { sözles }\end{array}$ \\
\hline
\end{tabular}

Yukarıda ki sol-sağ el işlem şemasına göre, hasta muayene süreci 8 dakika 46 saniye de; yani ortalama 9 dakikada tamamlanmıştır. Sol el ve sağ el hareketlerine de bakıldığında en çok zaman 'bekleme' ve 'işlem' sürelerine ayrılmıştır. Ancak bilindiği üzere sol-sağ el şemaları daha çok 
üretim faaliyeti gösteren işletmeler için gösterge teşkil etmektedir. Zira; bekleme süresi olarak belirttiğimiz şeklin açılımına bakıldığında; bu bekleme süresi boş geçen süreyi değil; hasta şikayetleri için dinlenirken, fiilen hareket etmeden geçen süreyi bize açıklamaktadır. Ancak, hangi işleme ne kadar süre ayrılıp, hangi işlemden ne kadar gerçekleştirildiğini bize göstermesi açısından faydalı olan bir şema olduğu açıktır. Siyah renk ile boyanan şekiller, hekim tarafından hangi sıra hangi işin yapıldı̆̆ını bize göstermektedir. Bu tabloya göre de; 9 dakikada toplam sürecin bittiği varsayıldığında ortalama 4'er dakika işlem ve bekleme (şikayet dinleme) süresine zaman ayrılmış; geriye kalan kısa süreler de 'kontrol', 'taşıma' ve 'tutma' süreçlerine ayrılmıştır.

Genel anlamda işin yapılış biçimi ve mahiyetine göre de bu süre ve işlemler değişiklik gösterebilmektedir. Burada örnek teşkil etmesi açısından sadece rutin bir muayene sürecini ele alınmıştır.

\section{Hemşire}

\subsection{Görev Tanımı ve İşlerinin Analizi}

Hemşire; en genel tanımıyla bireyleri, hastalıklardan korunma yolları konusunda bilgilendiren, beden veya ruh sağlığının bozulması halinde hekim tarafından verilen tedaviyi uygulayan, hasta bakımını planlayan, uygulayan, denetleyen ve izleyen kişidir (TC. Milli Eğitim Bakanlığı, 2013).

Genel olarak; hemşirelerin görevlerine şu şekildedir ;

$\checkmark \quad$ Hastayı kabul eder ve muayeneye hazırlar,

$\checkmark \quad$ Hasta bakımını yaparken, solunum, beslenme, boşaltım, hareket ve uygun pozisyon, uyku, dinlenme, uygun giyim, temizlik vb. temel insan ihtiyaçlarını dikkate alır ve uygulama yapar,

$\checkmark \quad$ Acil durumlarda ilk yardım tedavisi yapar,

Hasta için öngörülen tedaviyi uygular, takip eder ve düzenli olarak hastaya verilecek ilaçları temin eder, enjeksiyon yapar, serum takar, ameliyat yaralarını temizler, bandajlar, tansiyon ve vücut 1sısını ölçer, 
$\checkmark \quad$ Ameliyathanede fiziksel ortamı hazırlar, ameliyat ekibine yardimci olur,

$\checkmark \quad$ Hastaların genel durumları hakkında yazılı rapor tutar,

$\checkmark \quad$ Ana-çocuk sağlığı ve aile planlaması hizmetlerinin yürütülmesinde, insanların bulaşıcı hastalıklardan korunması ve istatistiki bilgilerin toplanması ve değerlendirilmesi gibi görevlerde bulunur (TC. Milli Eğitim Bakanlı̆̆ı, 2013).

Bir hemşirenin genel görevleri yukarıda belirtildiği gibidir. Araştırma konusu olan Mudanya Aile Sağlığı Merkezi'nde yetkili hekime bağlı olan bir hemşirenin görevler ve sorumlulukları şu şekilde özetlenmiştir ;.

\subsection{Mudanya 2 no'lu ASM'de Bir Hemşirenin Yaptığı Görev Ve Sorumlulukları}

$\checkmark$ Bebek, çocuk, gebelerin periyodik aşılamalarının yapılması,

$\checkmark \quad$ Bebek, gebe, çocukların her ay büyüme, gelişme izlemlerinin yapılır, gebelerin her ay gebelik takiplerinin yapılması,

$\checkmark \quad$ 15-49 yaş arası kadınların üreme gelişmeleriyle ilgili izlemlerinin yapılmas

$\checkmark \quad$ Hastaların obezite izleminin yapılması,

$\checkmark \quad$ Hastaların diabet izleminin yapılması,

$\checkmark \quad$ Özellikle 15-49 yaş arası kadınların ruh sağlığı izleminin yapilmas1,

$\checkmark \quad$ Günlük enjeksiyon, pansuman, sütur atımı gibi acil operasyonlar için müdahalede bulunmak,

$\checkmark \quad$ Ay sonlarında bütün yapılan işleri, istatistik çıkararak sağlık müdürlüğüne göndermek,

$\checkmark \quad$ Özellikle 15- 49 yaş arası kadınların hastalıklarıyla ilgili ölüm araştırmasını yapmak ve doktora analiz yapılması üzere araştırma sonuçlarını sunmak, 
$\checkmark \quad$ Çocuk ve bebeklerin boy, kilo, gögüüs, kol, baş çevresini ölçmek ve büyüme gelişimlerini değerlendirmek, sorun bulunan k1simları doktora iletmek,

$\checkmark \quad$ 15-49 yaş arası kadınların aylık takiplerinde, aile planlaması eğitimi verilmesi; beslenme durumları, Loğusa ise; emzirme danışmanlığı, evlilik/ gebelik öncesi üreme sağlığı danışmanlığ1, menopoz danışmanlığını yapmak ve bilinçlendirmek,

$\checkmark \quad$ 15-49 yaş arası kadınların evlendirme başlangıç işlemlerinin yap1lmas1.

$\checkmark \quad$ Ayrıca eklenmesi gereken önemli bazı görevler daha vardır. Bunları da önemle belirtmemiz gerekmektedir;

$\checkmark \quad$ Bir ay içerisinde bakılması gereken gebe, bebek, çocuk, 15-49 yaş arası kadın sayısı Sağlık Bakanlığı tarafından belirlenir. Bu belirlenen sayıya göre hemşire işlemlerini yapmak zorundadır. Aksi taktirde doktor ve hemşirenin performans ücretlerinden kesilme gerçekleştirilir,

$\checkmark \quad$ Senede bir kere nüfus tespiti yapılır. 'Bir hanede kaç kişi yaşıyor?", 'Medeni durumları nedir?", Yaşlılık durumları nasıl bir süreçten geçmektedir?" gibi durumlar araştırılır. Aynı zamanda, 'Evde içilen su türü', ' 'Kanalizasyon durumu", ' Aldıkları maaş ve ödedikleri vergi durumu" Eğitim, iş" durumu araştırılır ve gereken biçimde durum analizi yapılır.

$\checkmark \quad$ Hanede yaşayan kişilere komşu analizi yapılır(Hastanın bulunamadığı durumlarda bilgi almak için).

$\mathrm{Bu}$ gibi işlemlerin gerçekleştirilmesinin nedeni, hastaların ayrıntılı özlük bilgilerinin bilinmesi ve veri tabanına işlenmesi gerekliliğinden doğar.

Yukarıda belirtilen görevlerin yanında, ASM'de çalışan bir hemşirenin; bir hekimin sağ kolu olduğu söylenilebilir. Yardımcı sağlık hizmetlerinden, özellikle kadınların izlem durumlarına kadar tüm işlemlerde hekime yardımcı olmakla birlikte; bu görevlerden de ayrıca sorumludurlar. Sekretarya ve ebe görevlerini de ayrıca görmektedirler. 
Gözlemlenilen Mudanya 2 No'lu ASM'de, her iş günü hasta sirkülasyonundan dolayı oldukça yoğun geçmektedir. Araştırmanın yapıldığ 3 haftalık zaman diliminde de (15 iş günü), yoğun günler ve farklı işlemler gerçekleşmiştir. Özellikle hemşirelerin daha çok ayakta işlem yapmaları ve daha hızlı hareket etmeleri gerektiğini gözlemlenmiştir.

Araştırmada, gözlem yapılan günler içerisinden, hemşirenin rutin bir işgününden örneklem çıkarılmış; ayrıca iş akış diyagramı olarak da aktarilmıştır.

Bir iş gününde hemşirenin yaptığı işlere dair hazırlanan örnekleme tablosu aşağıdaki gibidir.

\section{Tablo 3: Hemşire Görev Özeti}

\begin{tabular}{|c|c|}
\hline Sira & YAPILAN İŞLERIN ÖZETİ \\
\hline 1. & $\begin{array}{l}08.00 \text { 'den itibaren, günlük yapılacak işlerin, işlemi ve izlemi olan } \\
\text { hastaların listesi çıkarılır. }\end{array}$ \\
\hline 2. & $\begin{array}{l}\text { 09.00'dan itibaren, yarım saat ara ile; gebe, bebek, çocuk ve } \\
15-49 \text { yaş arası izlemi olan kişilere randevu verilir. (30 kişiye } \\
\text { randevu verilmiştir) }\end{array}$ \\
\hline 3. & $\begin{array}{l}\text { Evlenecek olan } 3 \text { kişiye sağlık raporlarının verilmesi için kan } \\
\text { tahlili yapılmış̧ır. (Hemşire; aynı işlemleri olan kişileri arka } \\
\text { arkaya çağırmakta ve aynı grupta toplamaktadır) }\end{array}$ \\
\hline 4. & $\begin{array}{l}\text { İki Hamile bayan gelir, kimlik bilgileri dahilinde bilgisayara } \\
\text { gebelik bildirimi yapılır. Gebenin boyu, kilosu tansiyonu } \\
\text { ölçülür ve rutin kimya, biyokimya, hemogram, tit(tam idrara } \\
\text { tahlili) istenir. USG(Ultrasonografi) için ayrıca uzman hekime } \\
\text { yönlendirilir. Takribinde ruh sağllğı izlemi yapilır. (Kilit sorular } \\
\text { ile içinde bulunduğu psikolojik durum (eş şiddeti, depresyon,vb) } \\
\text { değerlendirilir. }\end{array}$ \\
\hline
\end{tabular}




\begin{tabular}{|c|c|}
\hline & \multirow{4}{*}{$\begin{array}{l}\text { Çocuklu bir bayan gelir. 0-6 yaş gruba dahil olduğu için rutin } \\
\text { izlem gerçekleștirilir. Boy, kilo, kafa, göğüs, kol çevresi ölçülerek } \\
\text { büyüme gelişimi izlenir. Bu işlemler veri tabanına işlenir. Çocuğun } \\
\text { beslenme durumu analiz edilir ve çocuk biraz zayıf bulunduğu için } \\
\text { anneye çocuk beslenmesiyle ilgili rutin eğitim verilir( } 10 \text {.dk sürer } \\
\text { ve resimlidir) Ayrıca; ev kazalarına karş1 önlem alma ve çocuğun } \\
\text { yaşına uygun oyuncak seçimi gibi konular hakkında bilgi verilir.. }\end{array}$} \\
\hline & \\
\hline & \\
\hline & \\
\hline & \multirow{2}{*}{$\begin{array}{l}\text { kadına, rutin meme muayenesi yapılır ve kitle olup olmadığ } 1 \\
\text { ontrol edilir. (1 kadının muayene süresi yaklaşık } 5 \text { dakika } \\
\text { ürmüştür }\end{array}$} \\
\hline & \\
\hline & \multirow{2}{*}{$\begin{array}{l}3 \text { Loğusanın tansiyon takibi, bacaklarında ödem olup olmadı̆̆ } 1 \text {, } \\
\text { kanama durumu, ateş derecesi ve emzirme danışmanlığı yapıldı. } \\
\text { Anne sütünün yararları anlatılıp, süt arttırıcı etkenler aktarıld1. }\end{array}$} \\
\hline & \\
\hline & \multirow{2}{*}{$\begin{array}{l}2 \text { Bebeğe rutin aşılama işlemi yapıldı ( } 4 \text { aylık bebeğe } 2 \text { adet; } 6 \\
\text { aylık bebeğe } 4 \text { adet aşı yapılldı, } 1 \text { aşı ortalama } 5 \text { dakika sürdü) ve } \\
\text { veri tabanına işlendi. }\end{array}$} \\
\hline & \\
\hline & \multirow{3}{*}{$\begin{array}{l}\text { Bir bayanın aile hekimi değiştirme işlemi gerçekleştirildi.(İkameti } \\
\text { değiştiği için Mudanya } 2 \text {. No'lu Sağlık Merkezi'ne kaydedildi). } \\
\text { Kimlik bilgileri veri tabanına işlendi ve 'evin reisi ‘'belirtmek } \\
\text { zorunlu olduğu için gelen bayan evin reisi olarak kayıt altına } \\
\text { alındı ( Bu işlem } 20 \text { dakika sürmüştür) }\end{array}$} \\
\hline & \\
\hline & \\
\hline
\end{tabular}

Rutin bir iş günü içerisinde, 0-6 yaş grubunu izlemine gelen anne ve 4 yaşındaki oğlunun izlem akış diyagramı aşağıdaki gibi aktarılmıştır; 


\section{Şekil 5 : 0-6 Yaş Çocuk İzlemi Akış Diyagramı}

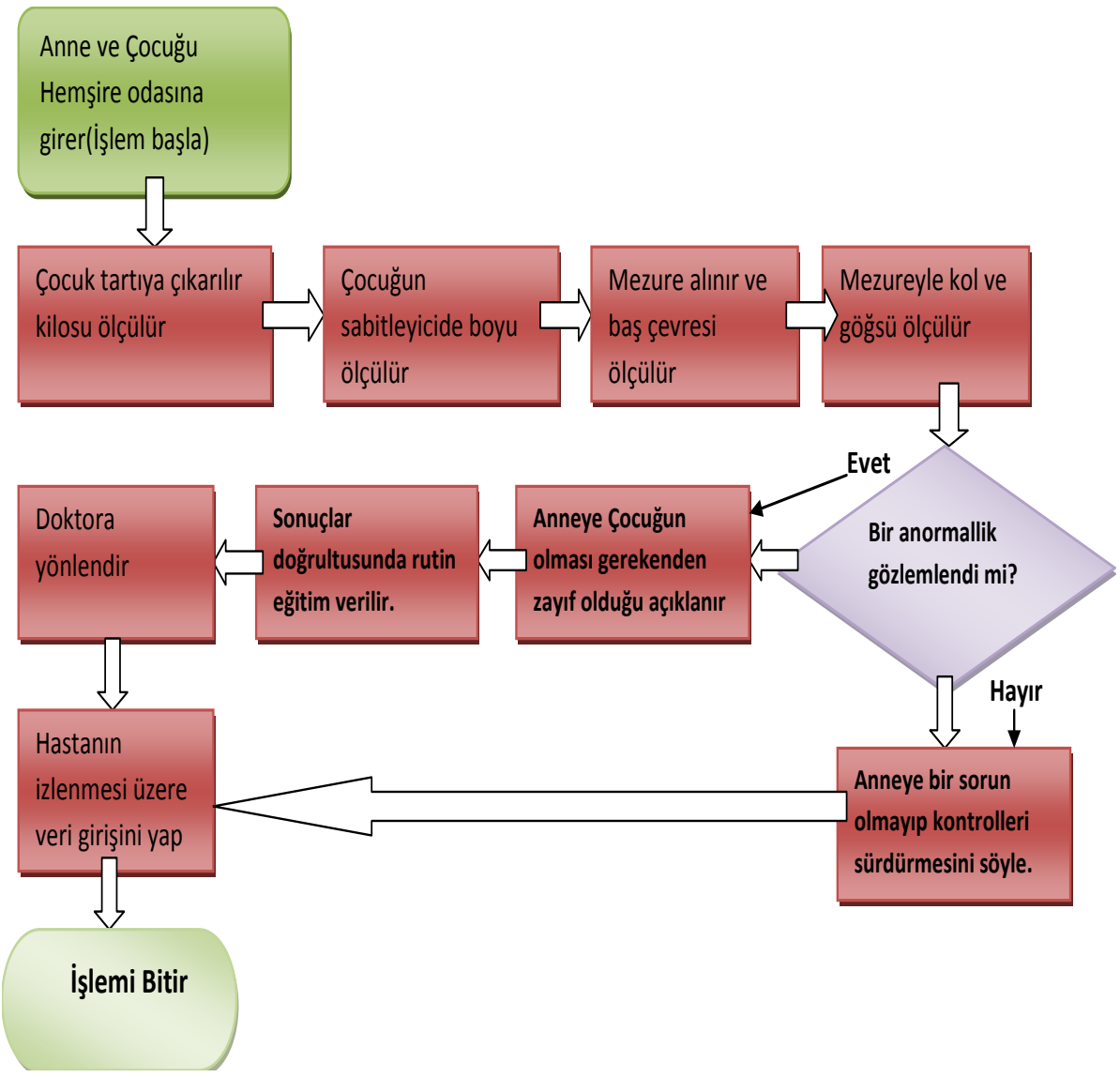

Yukarıdaki akış diyagramında, önceden belirlenmiş olan 0-6 yaş çocuk izlemi Gerçekleştirilmiştir. İşlem ortalama 20 Dakika sürmüş ve çocuğun, yaşıtlarıyla kıyaslandığında kilosu görece daha az bulunmuştur. $\mathrm{Bu}$ işlem sonrasında, anneye çocuk bakımı hakkında yineleyici bilgiler verilmiş (rutin eğitim) ve takribinde doktora yönlendirilmiştir. Doktor da gerekli bulursa, 2. ya da 3. Basamak sağlık merkezine yönlendirmek suretiyle izleme devam etmiştir. Hemşire bundan sonra, veri kayıt girişlerini güncellemiş ve çocuk hakkında bilgi verip işlemin gerçekleştirildiğini rapor etmiştir. Şayet çocuğun kilosu normal değerlerde olsaydı, anneye yine bunun hakkında bilgi verilip işlem sonlandırılacaktı. 


\section{$52 \cdot$ YALOVA SOSYAL BILIMLER DERGISI}

Bir ASM'de hekim ve hemşirelerin görevleri ayrıntılarıyla incelendiğinde, her gün ve belki dakika farklı ve çok çeşitli işlemler yapıldığı görülecektir. Ancak burada konunun bir kuş bakışı resmini çizmek amacıyla, kısa örnekler ve diyagramlar vermekle yetinilmiştir. Zira, özellikle aile hekimliği sistemi yürürlüğe girmesiyle beraber, işler eskisinden daha fazla hareketli ve rutin olmayan bir biçime

Yukarıdaki akış diyagramında, önceden belirlenmiş olan 0-6 yaş çocuk izlemi gerçekleştirilmiştir. İşlem ortalama 20 Dakika sürmüş ve çocuğun, yaşıtlarıyla kıyaslandığında kilosu görece daha az bulunmuştur. $\mathrm{Bu}$ işlem sonrasında, anneye çocuk bakımı hakkında yineleyici bilgiler verilmiş (rutin eğitim) ve takribinde doktora yönlendirilmiştir. Doktor da gerekli bulursa, 2. ya da 3. Basamak sağlık merkezine yönlendirmek suretiyle izleme devam etmiştir. Hemşire bundan sonra, veri kayıt girişlerini güncellemiş ve çocuk hakkında bilgi verip işlemin gerçekleştirildiğini rapor etmiştir. Şayet çocuğun kilosu normal değerlerde olsaydı, anneye yine bunun hakkında bilgi verilip işlem sonlandırılacaktı.

Bir ASM'de hekim ve hemşirelerin görevleri ayrıntılarıyla incelendiğinde, her gün ve belki dakika farklı ve çok çeşitli işlemler yapıldığı görülecektir. Ancak burada konunun bir kuş bakışı resmini çizmek amacıyla, kısa örnekler ve diyagramlar vermekle yetinilmiştir. Zira, özellikle aile hekimliği sistemi yürürlüğe girmesiyle beraber, işler eskisinden daha fazla hareketli ve rutin olmayan bir biçime bürünmüştür. Çok çeşitli hastaların, çeşitli nedenlerle ASM'ye gelmesi ve aynı zamanda muayenenin yanında destek, eğitim ve bilgilendirme maksatlı da ASM'de bulunması nedeniyle özellikle hemşirelerin de görev yükü ve sorumluluğu daha fazla artmıştır.

Bir ASM'de en önemli rolü oynayan figürlerden birisi de "Hastalar" olduğu için, bir hasta örneği ve akış şemasını da aşağıda belirtilmiştir.

\section{Hasta}

\section{- Hasta Örnekleri ve Analizi}

Bir Aile Hekimin ortalama 4000-4500 hastası olduğu düşünüldügünde hep aynı tip hastaların gelmediği açıktır. ASM'lere gelen birkaç hasta profili aşağıdaki özellikleri ile özetlenebilir ; 
$\checkmark$ Bir şikayeti olup, muayene için gelen hastalar (ateş, öksürük, halsizlik, mide sorunları, grip, nezle, kaşıntı, ishal, vb..),

$\checkmark \quad$ Sevk edilen hastalar (özellikle banka ve okullardan),

$\checkmark \quad$ Diabet ya da tansiyon gibi kronik rahatsızlı̆ğ olan hastalar,

$\checkmark \quad$ Sadece ilaç yazdırmak için gelen ya da ilaçları biten, e-reçete yazdiran hastalar,

$\checkmark \quad$ 15-49 yaş arası izlem için gelmesi gereken hastalar,

$\checkmark$ Gebeler (izlem),

$\checkmark$ Lohusalar (izlem),

$\checkmark$ Bebek ve 0-6 yaş grubu olan çocuklar (izlem),

$\checkmark \quad$ Sporcu, ehliyet yeterliliği, yivsiz silah yeterliliği gibi raporlar için gelenler,

$\checkmark \quad$ Evlendirme işlemleri için gelen kişiler

Genellikle bu tip hastaların ASM'lere gelmesinin yanında bu hasta tiplerini çoğaltmak mümkündür.

Hastaların ASM'ye ilk giriş ve çıkış süreçleri de değişiklik gösterse de; genellikle;

1. Hasta okutucu kartını alır,

2. Bilgisayar sisteminden hani doktora kaçta gireceğini öğrenir

3. Doktor koridorunda sirasını bekler

4. Surası gelince içeri girer

5. Doktor odasında işlem tamamlanır

6. İşlem tamamlanır / E-reçete alır/ Laboratuvara gider.

Ya da;

1. Hasta okutucu kartını alır,

2. Randevulaştığı saatte hemşire odasına gider, 
$54 \cdot$ Y YaLOVA SOSYAL BILIMLLER DERGISI

3. İşlemi hemşire odasında tamamlanır / Doktora yönlendirilir / Laboratuvara gider.

$\mathrm{Bu}$ süreçler, hastanın ASM'ye geliş nedenine göre çeşitlilik göstermektedir. Bu süreçlerden iki örneği, ASM'de gözlemlendiği şekliyle, konumuna göre "Akış Şeması" şeklinde aktarılmıştır.

Akış şemaları, proses akış şemalarının tamamlayıcısı olarak betimlenir. Buna göre, hareket yolunu gösteren ölçekli bir resimden ibarettir (Tanyaş, 1995).

Araştırmanın sürecinde karşılaşılan çok çeşitli hastalardan iki örnek, hareketleri gösteren akış şeması şeklinde aktarılmıştır. İlk Örnek A hastas1, 15 yaşında bir öğrencidir ve rapor almak isteğiyle ASM'ye gelmiştir. Diğer örnek B hastası ise, 64 Yaşında bir bayandır ve şekerine baktırmak isteğiyle ASM'ye gelmiştir.

\section{Şekil 6: A Hastası (Öğrenci)}

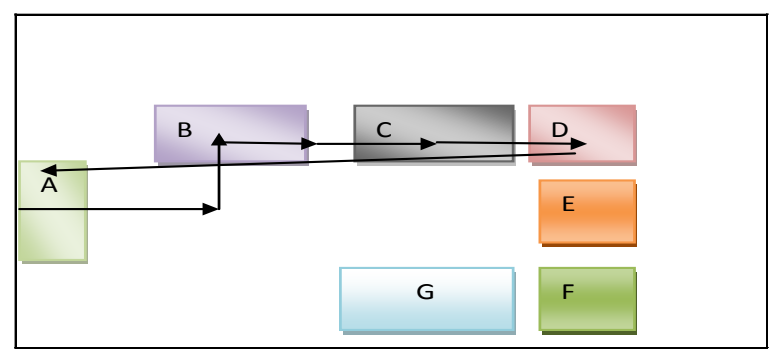

Yukarıda ki akış şemasında basit bir şekilde bir öğrencinin ASM'ye girip çıkışını görmektesiniz. Öğrenci ASM kapısından içeriye girer (A), Daha sonra Doktor için işlem sırası alır(B) ve sırasını bekleme salonunda bekler(C). Sırası gelince doktorun odasına girer (D). ASM'ye geliş nedeni, Okula gitmemek için rapor almaktır. Ancak doktor odasında kısa bir gözlem ile çocuğun hasta olmadığını anlar ve raporu vermez. Çocuk işlem yapılmadan gönderilir. (Oklarda görüldüğü gibi, çocuk geldiği yolu izleyerek ancak doktor odasından sonra(D) Başka işlem yapman geldiği kapıdan çıkar.(Bu işlem doktor yanında incelendiği için; bu süreç baz 
alındığında öğrencinin doktor odasına işlemi tamamlanıp girip çıkması; 2 Dakika sürmüştür)

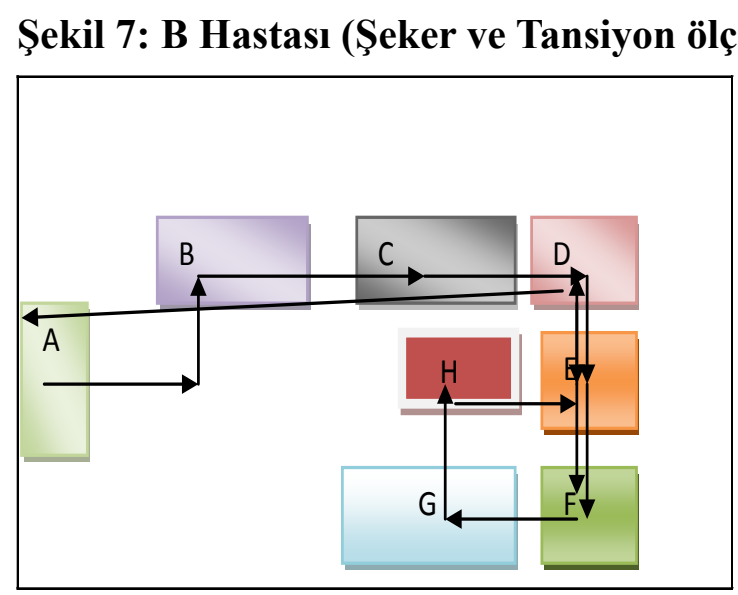

B hastası örneğinde ise; 64 yaşındaki bir hasta, son zamanlarda hissettiği rahatsızlıktan dolayı ASM'ye gelip sıra numarasını (barkodunu) alıp doktora muayene olmaya gelmiştir. Hasta doktor odasına çıkmış ve muayenesini olmuş; ilaçlarını da yazdırmıştır. Ancak hekim, hastanın şekerini tekrar kontrol etmek amaçlı Hemşireye yönlendirir(E). Sorumlu hemşire ise; Hastanın tansiyonunu ölçtükten sonra, hastayı kan örneği alınması Laboratuvara yönlendirmiştir(F). (Laboratuvarda hastanın kanı alınır-hemogram, biyokimya, hormon- bir tüpe kanı koyularak, Bursa'da ki merkez laboratuvara gönderilmek üzere hazırlanır, Ertesi sabah sonuçlar Merkez Laboratuvar tarafindan ASM'de ki sorumlu doktorun bilgisayarına gönderilir) Hasta ise bir müddet Hemşirenin dinlenme odasına alınmış(G), daha sonra tuvalete idrar tahlilinin de istenmesi üzerine gitmiştir. İşlemi bittikten sonra tekrar hemşirenin odasına gidip idrar tüpünü vermiştir. $\mathrm{Bu}$ işlemler olurken, doktor sorumlu hemşireye hastanın tansiyonundan da şüphelendiği için tansiyonunun ölçülmesini söylemiştir. Hemşire odasında (E) hastanın tansiyonu ölçüldükten sonra, tansiyonunun yüksek çıkması dolayısıyla tekrar doktora yönlendirilmiş; Doktor reçeteyi ek bir ilaç ile revize ederek, Hastanın yarına kadar dinlenmesini ve tahlilleri almak 
üzere ertesi güne gelmesini rica etmiştir.(Bu işlemler Doktor-Hemşire-Laboratuvar süreci göz önüne alınmış olup, hastanın ilk ASM'ye girişinden değil; ilk doktor odasına girmesiyle başlamıştır. Doktor odasından tüm işlemleri tamamlayıp ASM'den çıkması toplam 25 Dakika sürmüştür).

Yukarıda birbirinden oldukça farklı tipte iki hastanın giriş çıkışını basit bir şema ile ifade etmeye çalışılmışıtır. Her hasta tipi için şemalar ya da süreç şemaları; akış şemaları şekillendirilebilmektedir. Burada amaç Hasta-Doktor-Hemşire ilişkilerini bir bütünün ayrıntısı içinde incelemektir.

\section{Sonuç}

Üç hafta (15 İş günü) boyunca Mudanya 2 No'lu Aile Sağllk Merkezi'nde yapılan araştırma süresince toplam 1200 işlem + hasta izlenmiş; Toplam 5 hekimden, 2 hekim analiz edilmiş ve 2 hemşirenin yaptığ 1 işler izlenmiştir. $\mathrm{Bu}$ çalışmada, birkaç örnek sunmak yeterli görülmüştür. Nedeni ise, birçok işlemin birbirine benzemesi ancak; hastaların niteliği bakımından da işlemlerin değişiklik göstermesidir. Farklı işlemlerin ele alındığ hekim ve hemşirelerin işlemlerinde süreçlerin nasıl işleğini sunulmaya çalışılmıştır. Karşılaşılan en önemli sonuç; hemşirelerin iş ve hasta sirkülasyonun daha karmaşık bir süreçten geçtiği; hekimlerin ise, hastasına göre işlemlerinin 2 ila 10 dakika arasında değişiklik gösterdiğidir. Birinci Basamak Sağlık biriminde inceleme yapıldığı düşünüldüğünde, ikinci ya da üçüncü basamakta ki sağlık merkezlerine yönlendirmenin de var olduğunu açıktır. Performans ölçütlerinin ne kadar miktarda ya da ne kadar hızlı şekilde hasta muayene edildiğinden ziyade; Sağlık Bakanlığı tarafindan belirlenen kriterlerdeki kişilere (bebek, çocuk, gebe, 15-49 yaş arası kadın) ne sıklıkta izlem yapılıp, analiz edildiğinin önem teşkil edildiği saptanmıştır. Zira, edinilen bilgiler doğrultusunda, performans sistemi, hasta muayenesinden ziyade; bakılan bebek, çocuk, gebe, 15-49 yaş kadın izlem ve aşılar üzerinden ücretlendirilmektedir.

Bunların yanında, süre bazında ve işlem yapılan hasta sayısı göz önüne aldığımızda süreçlerin aksamadan hızlı ancak isabetli bir şekilde yapıldığı gözlemlenmiştir. Bunun nedenlerinden birisi; ASM'nin, merkez ilçelerine ( daha büyük ilçeler) nazaran küçük bir ilçe de olması ve genellikle

YIL: 5 SAYI: 10 
hekimlerin hastalarını tanıyıp; hasta profilinin bilinmesi olduğunu düşünülmektedir. Diğer nedeni ise; Pilot bölge olan Bursa'nın bir ilçesi olan Mudanya'da Aile Sağlığı Merkezlerinin aile hekimliği sistemine alışmış olduğu düşünülmektedir. Ayrıca; Aile Sağlığı Merkezleri; A,B,C,D olarak sınıflama kriterleri uyumuna göre derecelendirilmiş; Mudanya 2 No'lu Aile sağlığı Merkezi ise, B sınıfı kriterde hizmet vermeye başlamıştır. Bu da Sağlık İl Müdürlüğü'nden belirlenen kriterlere uyumun yüksek olduğu ve hasta memnuniyetinin makul durumda olduğudur.

Gözlemlenen başka nokta ise, hemşirelerin çalışma biçimleri arasındaki farklılıklardır. Araştırmanın yapıldığı hemşire örneği, kıyaslama itibari ile ideal olandır. Şöyle ki; Söz konusu hemşire, izlem yapılacak hastaları, izlemin yapılacağı gün aramakta ve izlem konusunda aksamaların önüne geçmektedir. Zira, diğer bir hemşire, söz gelimi izlem yapılacak kişileri bir hafta önceden aramakta, ve izlem yapılacak kişiler bir hafta sonrasına randevusu olduğunu unutmakta ya da işleri olduğu gerekçesiyle izleme gelmemektedirler. Bu da gözlemlendiği kadarıyla, o izlemeleri yapacak hemşirenin işlerini aksatmakta ve boş geçen zamana neden olabilmektedir. Dolayısıyla izlem yapılacak önceden tespit emiş hastaları, izlem yapılacakları gün çağırılmaları, daha iyi sonuç vermektedir.

Bunların dışında, hastalara işlem yapma durumundaki iki hekimin analizinde, iki hekimin aynı tip hastaya bile çok fazla zaman farkı olmasa da farklı sürelerde işlem yapıldığı gözlemlenmiş̧ir. Bunun nedeni; ' Bir hekim hasta ile daha fazla ilgilenirken, diğeri sadece işlem hızına mı odaklı çalışıor?" ya da " yine yukarıda ki örnekle olduğu gibi; "'bir hekim bir çocuğa ortalama, 9,5 dakikada aşılama yaparken, neden aynı işlemini diğer doktor 1,8 dakika da yapıyor?" diye sorgulanmıştır. Daha sonra hemşirelerin işlemleri gözlemlendiğinde, bazı çocuk aşılama işlemlerinde o çocukların niteliğinden ( her hangi bir sorun bulunuyor ise) daha fazla işlem yapıldığını ya da ailelere açıklama yapıldığını; diğer çocuğa ise sadece aşılama işlemini hemşirenin yapıp işlemi bitirdiğini ve işlem verilerini hemen bilgisayar kaydına girdiği saptanmıştır. Sonuç olarak performanstan ziyade, yapılan işlemin niteliğinden dolayı zaman farkları olduğu tespit edilmiştir. 
- YALOVA SOSYAL BILIMLER DERGISI

\section{Kaynaklar}

Bursa Sağlık Müdürlüğü (2009) Aile Hekimliği Uygulama Rehberi, Bursa

DOĞRUER, Mete (2008), “'Işs Etütü’, Açılım Kitap, İstanbul.

KOBU, Bülent (1999), ‘Üretim Yönetimi”, Avcıl Basım, İstanbul.

KORUKLUOĞLU, S., Y.Üstü, İ.Kasım, R.Doğusan ve A.Haciimamağaoğlu; (2004), "Aile Hekimliği Türkiye Modeli", Mavi Ofset, Ankara.

KURT, M., M. Dağdeviren; (2003), “'Işs Etütü’, Gazi Kitapevi, Ankara.

ÖZCAN, S., S. Yavuz, M. Deveci; (2011), ‘'Bir İşletmede Zaman Etütü Ve Simülasyon Çalışması”, Sageya Yayıncılık, Ankara.

SABUNCUOĞLU, Zeyyat (2011), İnsan Kaynakları Yönetimi, Beta Basım A.Ş., 5.Bask1, İstanbul.

ŞAHIN, Tayfun (2012), Aile Hekimliği Hukuku, Nobel Tıp Kitapevleri, İstanbul.

TANYAŞ, Mehmet; (1995), 'Endüstri Mühendisliğine Giriş”, İrfan Yayımcılık, İstanbul.

TC. MILLİ EĞİTİM BAKANLIĞI; (2013), 'Hemşirelik”, http://mebk12.meb. gov.tr/meb_iys_dosyalar/10/04/973874/icerikler/hemsirelik_212569. html, 05.02.2015.

TEKİN, M., (1996) Üretim Yönetimi Cilt 1: Yenilenmiş 6. Bask1, Güney Matbaas1, Konya

TEKİN, N., O.Başak, A.Yıldırım; (2010), 'Türkiye'de Aile Hekimliğinin Kökenleri Ve Gelişimi: Yarım Yüzyıllık Bir Hekim Deneyimi”, Türk Aile Hekimleri Dergisi, Cilt:14, Sayı:1, s.13-21.

YIL: 5 SAYI: 10 